\title{
Teaching Innovation of Professional Course of Postgraduate in Materials Science*
}

\author{
Hui Tang ${ }^{\mathrm{a}}$, Wenxue Wang ${ }^{\mathrm{b}}$, Shanshan $\mathrm{Hao}^{\mathrm{c}}$, Baojun $\mathrm{Ge}^{\mathrm{d}}$ \\ School of Materials Science and Engineering Harbin University of Science and Technology \\ Harbin 150080 China

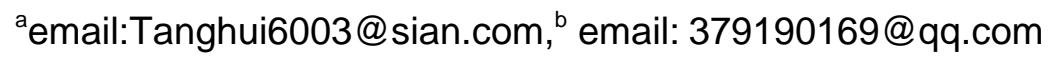

Key words: postgraduate education; professional course teaching; teaching reform; materials science

\begin{abstract}
Professional course teaching is one of the effective ways of educating postgraduate. According to the characteristic and training objective requirement of professional course teaching about engineering master of modern materials science, this paper analyzes the shortage of current course teaching. Also, the paper discuss the reform and innovation of postgraduate course teaching in many ways of optimizing postgraduate professional course system, professional skeleton curriculum provision,

postgraduate course teaching reform, practice teaching platform and base construction of professional skeleton course.

In recent years, with the increasing of postgraduate enrollment, postgraduate course teaching becomes more and more important and has been one of the effective ways to guaranty the postgraduate teaching quality[1]. Now, the function of postgraduate course teaching has two points: through solving problems to obtain knowledge and obtaining knowledge to solve problems. The two functions are not acted counter but two kinds of manifestation of postgraduate ability training. The form of "solving problem - obtaining knowledge - solving problem " accords with the inherent law of postgraduate education[2]. To postgraduate, course study is a process of grasping knowledge. Through scientific theory course study for one year, then developing research practice is not only necessary but also according with the law of postgraduate education.
\end{abstract}

\section{Disadvantages of traditional course teaching about postgraduate of materials science}

Emphasize "profession" and neglect "erudition”

For a long time, postgraduate education emphasizes professional knowledge and skill excessively, which lead that professional education limit to postgraduate curriculum provision system, teaching plan, syllabus, teaching content and teaching material writing[3]. With the coming of knowledge economy era, interdisciplinary and frontier science are constantly emerging. It is difficult to use one branch of professional knowledge to solve problems. The thought of professional education has not been according with the demands of era and quality education. While because of extensive knowledge, general person has got interdisciplinary or cross-disciplinary academic foundation, academic view and comprehensive ability. He can grasp inner relations between subjects or majors better. General education completely accord with the demands of postgraduate quality education in our country.

Emphasize "teaching” and neglect "discussion"

Classroom teaching is always a main instructional mode of postgraduate teaching and imparting knowledge for its purpose. Teaching mainly use the mode of "blackboard writing + explanation + wall map" or "multimedia + blackboard". This mode is a simplify teaching method of centering the teacher, textbook and class[4]. The mode is "cramming education" and "injection type" with one chalk, one blackboard, one computer, one teacher and numerous students. Teacher is subject and student is object. Teachers emphasize inculcating numerous knowledge to students and get used to making students' brain be full of existing knowledge of science and technology. They demand students to accumulate and learn knowledge that predecessors leave. Teachers use how much 
knowledge the students remember to reflect teaching efficiency and evaluate their academic records. While students pursue the standard answers that textbooks or teachers give and they have no chance to ask questions or communicate and discuss with teachers at class, common thinking is trained. For a long time, this teaching method makes students lack of learning enthusiasm, the spirit to be diligent in thinking and brave in questioning. It results in decreasing students' learning ability, practical ability and innovation ability, and it also goes against cultivating students' practical ability, exploration spirit and creativity.

emphasize "theory" and neglect "ability"

Improvement of postgraduate cultivation quality is the core of postgraduate education at school. Personnel training in postgraduate level emphasizes research and innovation. Postgraduate realize cultivation of innovation ability mainly through finding and then solving problems by themselves. For the purpose of cultivating innovation ability, postgraduate must have got complete knowledge structures and professional skills. It depends a great extent on special postgraduate course. So, postgraduate course teaching is not only a need of knowledge inheritance and widen foundation, but also a necessary mean of cultivating their innovation ability[5]. The ultimate goal of postgraduate course teaching is to grasp research method and cultivate ability of solving practical problems. But, because of lack of experimental teaching equipment, lag of experiment condition and not making the best of existing high-quality teaching and research conditions in postgraduate practice teaching, postgraduate's cultivation of research ability is not systematic or comprehensive enough on the stage of course study. Lack of comprehensive research training results in postgraduate entering graduate issue research state slowly. It seriously constrains improvement of postgraduate research innovation ability and practice ability, and it effects the quality of postgraduate cultivation immediately.

\section{connotation of course teaching reform about engineering postgraduate of modern materials science}

Setting up unique modern postgraduate course system

Postgraduate should have solid basic theory and systematic special knowledge. Postgraduate grasp basic theory of the respective discipline and stability special knowledge through course study. Meanwhile they can know development and frontier knowledge of the discipline well so that they form a reasonable knowledge structure to fit the need of development of science and technology and national economic construction. So, postgraduate course emphasizes foundation, comprehensiveness and practicability. Degree courses in training plan should cover a wider range of knowledge, widen postgraduate's knowledge area and emphasize improving postgraduate's humanistic quality. Knowledge structure of postgraduate course should have a characteristic of broad fields that it makes a further study of this major and learns knowledge of related fields widely. The knowledge structure of postgraduate course should be set up like concentric circles which center at professional course, take high correlated course as small radius and low correlated course as big radius. This structure makes for postgraduate's personalized development on their majors.

Usage of modern teaching methods and means

Postgraduate course teaching should change one-way instillation to modern teaching methods such as discussion at class. Teachers can find postgraduate's interests in time through discussion at class so as to adjust teaching plan. In this teaching mode, teachers are not only the instructor of knowledge, but also the guide of study. The responsibility of teachers is to lead postgraduate to give their different opinions to new knowledge on the foundation of previewing lessons and make a further discussion. It makes students get used to surveying all with critical opinions and dare to challenge authority so that students' ability of dialectical thinking and questioning spirit are cultivated. Highlight teachers' innovative teaching thinking - "guidance, service, interaction" - that students are subjects and teachers are leaders. Teachers encourage students to learn by themselves and cultivate their exploring learning ability. In the past teachers put emphasis on learning outcomes only. Now in the modern teaching mode teachers emphasize students' learning process and methods as well as learning outcomes. Try new teaching mode of interaction between teachers and students, such as: discussion, inspiration, case, experience, question or observation teaching, multimedia 
teaching, scene teaching, interaction teaching and so on. Infiltrating modern teaching methods and skills into each lesson and cooperating Supported with modern teaching means and advanced teaching contents attain expected goals.

ways of cultivating innovation practical ability

Companies emphasize postgraduate's practical ability more and more. It is very hard to cultivate postgraduate's practical ability through classroom teaching. The only way is to make more chances for postgraduate to participate in practice and set up diversified practical teaching concept. Bring the comprehensive education function of practical teaching into full play and combine course study with scientific subject research organically. The mechanism centering at scientific research makes students study professional theoretical knowledge as well as participate in scientific research. Postgraduate know the standard and procedure of scientific research well and their scientific research ability and innovative consciousness are developed greatly.

\section{Reform and innovation of postgraduate course teaching about modern materials science}

Setting up cultivation plan seriously, building up course system

Tab.1 is the course system of four major fields of materials engineering postgraduate. Materials science has four research fields: (1)inorganic nonmetallic materials; (2)metallic materials; (3)organic polymer materials; (4)composite materials. Different courses are set up depending on different major fields. In the first term there are seven foundation theory courses which students must complete. In the second term there are compulsory course and optional course. Students of four majors can choose 5 compulsory courses and 3-5 optional courses depending on their tutor's research direction. Compulsory course embodies "profession" and optional course embodies "erudition”. For example, a student whose major is inorganic nonmetallic materials should choose these compulsory courses: (centre); these high correlated courses as optional courses:(small radius); and these low correlated courses as another group of optional courses: (big radius). Also they can choose interdisciplinary courses that are set up by other schools such as School of Applied Science, School of Electrical Engineering or School of Chemical Engineering. The characteristic of "erudition” is fully embodied.

TABLE1 CULTIVATION PLAN AND COURSE SYSTEM OF MASTERS ON MATERIALS

\begin{tabular}{|c|c|c|c|}
\hline \multicolumn{2}{|r|}{ Degree curriculum } & \multicolumn{2}{|r|}{ Degree curriculum } \\
\hline Course number & Course name & Course number & Course name \\
\hline S000104 & Dialectics of Nature & & \\
\hline $\begin{array}{l}\text { S000105 } \\
\text { S000101 } \\
\text { S000102 } \\
\text { S000103 }\end{array}$ & $\left.\begin{array}{l}\text { Scientific Socialism Theory Practice } \\
\text { English } \\
\text { Japanese } \\
\text { Russian }\end{array}\right\} \quad$ Choose any one & $\begin{array}{l}\text { S000108 } \\
\text { S000106 } \\
\text { S020105 } \\
\text { S020101 } \\
\text { S020102 }\end{array}$ & $\begin{array}{l}\text { Mathematical Statistics } \\
\text { Numerical Analysis } \\
\text { Quantum mechanics and Solid State Physics } \\
\text { Analysis Methods of Materials1 } \\
\text { Analysis Methods of Materials2 }\end{array}$ \\
\hline \multicolumn{4}{|c|}{ Compulsory and optional curriculum } \\
\hline Course number & Course name & Course number & Course name \\
\hline S000111 & Sports and Fitness & S020213 & materials processing and Test \\
\hline S000114 & Teaching practice & S020214 & Material forming process and Numerical simulation \\
\hline S000112 & English & $\begin{array}{l}\text { S020215 } \\
\text { S020216 }\end{array}$ & $\begin{array}{l}\text { Metallurgy transport phenomena } \\
\text { Alloy histology }\end{array}$ \\
\hline S020201 & $\begin{array}{l}\text { Polymer blending modification and } \\
\text { processing and molding }\end{array}$ & S020217 & Modem mould manufacture \\
\hline S020202 & Inorganic nonmetallic Composite & S020218 & Material connection and Physical process \\
\hline S020203 & $\begin{array}{lcr}\text { Principle of } & \text { Solid-state } & \text { Phase } \\
\text { Transformation } & \text { of } & \text { Metallic } \\
\text { Materials } & & \\
\end{array}$ & S020219 & New forming processing of Advanced materials technology \\
\hline $\begin{array}{l}\text { S020204 } \\
\text { S020205 } \\
\text { S020206 }\end{array}$ & $\begin{array}{l}\text { Polymer matrix composite } \\
\text { Metallic matrix composite } \\
\text { Science of Ceramic Material } \\
\end{array}$ & $\begin{array}{l}\text { S020220 } \\
\text { S020221 } \\
\text { S020222 }\end{array}$ & $\begin{array}{l}\text { CAD design of Material forming } \\
\text { Design of experiment } \\
\text { Materials synthesis and fabrication }\end{array}$ \\
\hline $\begin{array}{l}\text { S020207 } \\
\text { S020208 }\end{array}$ & $\begin{array}{l}\text { DynamicNon-Destruction } \\
\text { Measurement } \\
\text { Ecomaterial }\end{array}$ & $\begin{array}{l}\text { S020223 } \\
\text { S020224 }\end{array}$ & $\begin{array}{l}\text { Introduction to microelectronic capsulation and micro- } \\
\text { connection } \\
\text { Light alloy materials }\end{array}$ \\
\hline $\begin{array}{l}\text { S020209 } \\
\text { S020210 }\end{array}$ & $\begin{array}{l}\text { New inorganic materials } \\
\text { new insulation material }\end{array}$ & $\begin{array}{l}\text { S020225 } \\
\text { S020232 }\end{array}$ & $\begin{array}{l}\text { Wear resistant material } \\
\text { Theory of material processing }\end{array}$ \\
\hline
\end{tabular}




\begin{tabular}{|c|c|c|c|}
\hline & & S020233 & Material processing control \\
\hline $\begin{array}{l}\text { S020251 } \\
\text { S020252 }\end{array}$ & $\begin{array}{l}\text { Functional polymer material } \\
\text { Functional Inorganic non-metallic } \\
\text { materials }\end{array}$ & $\begin{array}{l}\text { S020234 } \\
\text { S020235 }\end{array}$ & $\begin{array}{l}\text { Special plastic molding } \\
\text { experimental teaching ( SEM 和 XRD) }\end{array}$ \\
\hline
\end{tabular}

Accelerating reform of teaching methods and means

Postgraduate teaching inspire postgraduate to think by themselves through presenting research and exploratory problems. It makes postgraduate raise and solve problems in process of thinking. The sense of postgraduate's finding problems is formed and their comprehensive ability is improved too. Inspire teachers to use advanced postgraduate teaching theory and modern teaching means to improve teaching quality. Various teaching methods can be used such as teaching, self-study, discussion, case and observation teaching. Combining subjects, self-study, references, writing papers with class discussion organically can inspire students' study initiative and improve teaching quality.

\section{Cultivating innovative practical ability and setting up practical teaching platform}

To improve postgraduate's innovation, practical and research ability, schools set up the Fund for Postgraduate's Research and Innovation, open practical platform and postgraduate training base cooperating with companies. Schools improve all practical link and make the foundation of forming innovative teaching system for postgraduate of materials science.

In the background of expanding enrollment of masters and reforming teaching system, the key of balanced development of postgraduate education scale, quality, structure and benefit is to adapt the need of modern teaching reform actively, build up innovative education concept and reasonable course structure of major, explore diversified teaching methods and means, and build up high-level practical teaching base.

\section{Acknowledgment}

This work was Supported in part by Key Project of Higher Education Teaching Reform of Heilongjiang Province 2011(201105) and Special Project of Higher Education Teachin Reform of Higher Education Teachin A ssociation China 2011 (2011HYZX021) and Special Project of Higher Education Comprehensive Reform of Heilongjiang Provinc

\section{References}

[1] 1.Wang shengyi, Xue wenpeng. Thinking on Graduate Teaching Reform China Agricultural Education. 2005(2)

[2] 2.Zhao mengcheng. Application of problem-based Learning in Graduate Teaching. Jiangsu Higher Education. 2003(4)

[3] 3.Qin yuanjian. Graduate courses teaching method of LPC. China Higher Education Research. 2005(8)

[4] 4.Jin hongmei. Rediscover the meaning of the teaching improvement of graduate courses Academic Degrees \& Graduate Education. 2008(9)

[5] 5.Xing xiaohui, He meirong, Ling zhaohui. Teaching cultivation as a point of scientific research ability of postgraduates .Forum on Contemporary Education. 2008(11) 